\title{
The Challenge of Teacher Quality and Human Development in Nigeria
}

\author{
Adedapo S. Adelokun, Oluwatoyin B. Akinola \\ Obafemi Awolowo University, Ile-Ife, Nigeria
}

\begin{abstract}
Teaching has been changed from what it used to be in Nigeria. The change has been in structure and quality. The increasing expansion of pupils' enrolments at both the primary and secondary schools has led to the existence of six categories of teachers with different academic qualifications. This paper explored the levels of these qualifications and their influence on Human Development Index (HDI) including Life Expectancy Index (LEI), Education Index (EI), and Income Index (II). The study adopted the descriptive research design by collecting data on the quality of primary and secondary school teachers from ministries of education in 20 of the 36 states in Nigeia. The "Categories of Primary and Secondary School Teachers' Checklist" was given to the planning units of the affected ministries for completion. The responses were then thematically analysed and discussed. It was discovered that the quality of teachers in $80 \%$ of the sampled states may be incapable of boosting the HDI of the states in Nigeria. This is because of the relatively high percentage (15\%) of voluntary corps members and part-time teachers (state-organised employment opportunity programme) employed particularly at the secondary school level in the south-west; and high percentage of unqualified teachers in the northern states (up to $76 \%$ in Bauchi State). It was concluded that specific guidelines for teachers' recruitment at both primary and secondary school levels be legislated upon and enforced across the states in Nigeria in order to ensure improved HDI.
\end{abstract}

Keywords: Life Expectancy Index (LEI), teacher quality, Income Index (II), qualifications, Education Index (EI)

\section{Introduction}

In its 2008 edition of the World Bank Report, the World Bank ranked Nigeria 61st in the formal unemployment scale in the world with $4.9 \%$ unemployment rate (Word Bank, 2008). This has further worsened the poverty rates in Nigeria since unemployment is a major determinant of poverty rates.

The three major stakeholders in the public education industry are teachers, clients, and government. The effectiveness of collaborative efforts of these stakeholders however rests most on the teachers and their inputs which are directly related to their quality. Teacher quality, in this paper, is discussed using the indicator of qualification. Two of the hallmarks of teaching are the knowledge of content and the technology of pedagogy.

These are the hallmarks of the training programme of teacher education which the unqualified teachers may not possess. These competencies are further advanced by Perresnoud (1999) with managing student learning progression, working in teams, and tackling professional duties and ethical dilemma. These, to a large extent, predetermine teachers' levels of productivity in Nigeria; teachers with various qualifications are 
employed. These include teachers with university degrees (Bachelor of Education (B.Ed.), Bachelor of Arts (B.A.), Bachelor of Arts in Education (B.A.Ed.), Bachelor of Science (B.Sc.), Bachelor of Science in Education (B.Sc.Ed.)), teachers with Nigeria Certificate in Education (NCE), teachers with Higher National Diploma (HND), and teachers with Ordinary National Diploma (OND). Teachers with teaching qualifications (B.Ed., B.Sc.Ed., or B.A.Ed.) and NCE holders are further subdivided into permanent and voluntary corps cadre organized by the state governments for participants to teach for two years on a salary usually not higher than NGN10,000 a month as found in Ondo, Osun, and Edo states. There is also the National Youth Service Corps (NYSC) (established in 1974) cadre posted to states by the central government to serve in various public and private establishments including schools.

The contribution of schooling to economic growth has remained a topical issue in the discourse on human capital formation since the 1960s (Bowman \& Anderson, 1963; Lewis, 1961; UNESCO, 1962; Schultz, 2001 (as cited in Adelokun, Ajayi \& Oni, 2010); Denison, 1963; Eicher, 1960; Aromolaran, 2002; Babatunde \& Adefabi, 2005; Barouni \& Broecke, 2012; Hector, 2006; Saharawati, 2008; Sackey, 2008).

Patrinos (2014) called nations' attention to the need to encourage education at public cost in order to ensure quality, but defined in terms of "public system" which includes households, the private sector, and the government structure. Patrinos (2004) further advocated that the public sector should "learn, disseminate, and regulate" education. Teacher quality is one of those factors which should be regulated. With these, the emphasis should be shifted to disseminating what the private education providers do to their teachers, which have added value and innovation to teacher quality. The six goals of the World Bank Forum in Dakar, Senegal, in 2000, reiterated the need for quality in all aspects of education in member states with the concurrence of the "Education for All" (EFA) proponents. Thus, the EFA programme should be stressed at both primary and secondary education levels (UNSCO, 2014). Teacher quality, in this regard, is perceived from the quantity and quality perspectives. The quantitative aspect of teacher quality focuses on adequacy of qualified teachers, while quality refers to the depth of qualifications of such teachers.

Most of the early authors on economics of education (Eicher, 1960; Denison, 1963) argued for the positive contribution of education to economic growth and human capital development. Schultz (1961) (as cited in Adamu, 2003) itemized five ways of developing human capital as:

(a) Investment in health facilities and services;

(b) On the job training in form of apprenticeship;

(c) Formally organized education at all levels;

(d) Study programmes, such as agricultural extension (in form of agriculture education);

(e) Migration of individuals and families to adjust to changing job opportunities.

It was observed that, of these five means of developing human capital, the last three are associated with schooling or formal education. Formal education, at the primary, secondary, and tertiary levels, has the potential of widening job opportunities, increasing income, and by so doing, widening access to some expenditure, and thereby increasing consumption (Adelokun, Ajayi, \& Oni, 2010).

All these are based on the assumption of taking teaching and teacher quality as given. In the Nigerian context, despite the promulgation of Universal Basic Education (UBE) Act in 2004, which makes the first nine years of schooling free and compulsory, the number of out-of-school children, exacerbated by high repeater and drop-out rates, increased from 6,000,000 in 2002 to 9,000,000 in 2011 and projected to 10,500,000 in 2014 (United Nations International Children's Emergency Fund (UNICEF), 2012). Yet, teachers of various 
categories are employed in most of the 36 states annually to replace the retired ones. It was argued here that the level of influence which education has on the economy is a function of the quality of teachers available for the process when the teaching-learning process is perceived from the systems theory perspective.

In the measurement of human capital index, various models have been adopted (Griffin \& Knight, 1990; United Nations Development Programme (UNDP), 1990). Since macro-economic variable of Gross Domestic Product (GDP) per capita has not shown sufficient proof of the standard of living of Nigeria, the indicators of human development, such as Life Expectancy Index (LEI), Education Index (EI), and Income Index (II), focus on micro-economic variables. These are treated in turns below.

Life expectancy is defined (in statistical sense) here as the average age which an individual who is of $x$ age has left before he dies at age $x+u$, where $u$ is unknown but fixed as average due to previous analysis of the country.

Nigeria's LEI increased from 47.56 years in 2008 to 51.9 years for the total population in 2011. This, according to the UNDP (2012), was because of improved provision of potable water, sanitation, and child mortality. Health education, which is carried out by teachers and government agencies, thus paid off. However, this was at the national level. Across the states of Nigeria, the LEI varies from region to region. UNDP (2014) reported a substantial improvement in the LEI in the southern region of Nigeria but a worsened condition in the northern states. This may not be unconnected with the preponderance of unqualified teachers in both primary and secondary levels of education in most of the northern states.

In spite of the much-advanced arguments for the role of education in the reduction of poverty in countries (Weisbrod, 1963 (as cited in Adelokun, Ajayi, \& Oni, 2010); Colclough, Kingdon, \& Patrinos, 2009) supported by evidences from the experience in advanced countries, the status of Nigerian education system, even when the nation introduced free education at all levels during the military era, has not alleviated poverty in the country. The Human Development Index (HDI) including LEI, II, and EI has been worsening over the recent years (2005-2012) while LEI has been rising, though slowly, due to the privatization of the health sector and access to health education in Nigeria. These unfavourable trends in the three indicators have culminated in worsened standard of living and higher poverty rates. With education on the concurrent list, state governments have saddled themselves with the establishments of more secondary schools for both political patronage and/or necessity. To meet the needs of the teeming secondary schools, teachers of various categories are employed. There is doubt however that whether these teachers could meet the quality criterion for improving lives in terms of LEI, EI, and II of the products of these schools. This study examined the quality of secondary school teachers in Nigeria and its influence on the development of the products of secondary schools in Nigeria. This was with a view to locating the nexus between the quality of teachers in Nigeria's secondary schools and the indicators of LEI, EI, and II.

\section{Method}

The study focused on the nexus between human development and education which was defined as schooling by exploring the levels of education across Nigeria and the three indicators of human development. This was with a view to delineating how teacher quality would assist in achieving improved LEI, II, and EI in Nigeria.

The study adopted a descriptive research design. The population covered 36 states in Nigeria while proportionate random sampling technique was used to select 20 states with seven, 10, and three states sampled in the south, north, and west respectively. Data on quality of teachers in Osun State secondary schools in 
Nigeria were collected from the State Ministry of Education. These were thematically analysed and discussed against the backdrop of the HDI of Nigeria using Ghana as a reference point. This paper focused on 20 of the 36 states of Nigeria whose data on secondary education were available. The 2009 data on primary education from the Federal Ministry of Education were of essence. The data on secondary education centered on Osun State whose details were also available.

\section{Results}

The secondary data gathered on Ghana and Nigeria's LEIs are presented in Table 1.

Table 1

LEIs of Nigeria and Ghana (2001-2012)

\begin{tabular}{llllllllllllll}
\hline Country & 2000 & 2001 & 2002 & 2003 & 2004 & 2005 & 2006 & 2007 & 2008 & 2009 & 2010 & 2011 & 2012 \\
\hline Nigeria & 51.56 & 51.07 & 50.59 & 51.01 & 50.49 & 46.74 & 47.08 & 47.44 & 46.53 & 46.94 & 47.24 & 47.56 & 52.05 \\
Ghana & 57.42 & 57.24 & 57.06 & 56.53 & 56.27 & 58.47 & 58.87 & 59.12 & 59.49 & 59.85 & 60.55 & 61 & 61.45 \\
\hline
\end{tabular}

Note. Source: Adapted from World Bank (2013).

A critical look at the LEIs of Nigeria above shows a steady decline from 2000-2009 before the peak of 52.05 in 2012. The decline might be as a result of multiple factors, but quality education which comes from the use of quality teachers is not exempt. On its own part, Ghana recorded slight decreases from 2000 to 2004 (from 57.42 to 56.27) and gradual increases till 2012 (61.45). It is argued here that the quality of education of the citizenry in both countries accounts for the observed status. The quality of education is a product of quality teachers.

Data on quality of teachers were also collected from the ministries of education of 20 of the 36 states in Nigeria (see Table 3).

Table 3

Quality of Primary School Teachers by State and Qualification (2009)

\begin{tabular}{llcccl}
\hline S/N & State & Graduates above NCE & Below NCE & Others & Unqualified (\%) \\
\hline 1 & Abia & 7,048 & 5,306 & 2,188 & 43 \\
2 & Bayelsa & 1,934 & 2,414 & 170 & 56 \\
3 & Cross River & 8,334 & 3,096 & 2,471 & 40 \\
4 & Ebonyi & 2,973 & 2,519 & 1,441 & 63 \\
5 & Edo & 8,219 & 2,833 & 1,957 & 26 \\
6 & Imo & 12,379 & 4,484 & 2,986 & 27 \\
7 & Rivers & 6,696 & 1,874 & 1,518 & 23 \\
8 & Adamawa & 5,579 & 8,564 & 2,504 & 61 \\
9 & Bauchi & 2,930 & 9,474 & 2,196 & 76 \\
10 & Benue & 14,601 & 7,030 & 3,830 & 32 \\
11 & Borno & 5,157 & 5,974 & 1,971 & 54 \\
12 & Gombe & 2,969 & 5,382 & 1,479 & 64 \\
13 & Jigawa & 2,261 & 6,059 & 1,473 & 73 \\
14 & Kano & 6,473 & 13,198 & 3,483 & 67 \\
15 & Katsina & 2,981 & 6,359 & 1,654 & 68 \\
16 & Sokoto & 2,021 & 4,042 & 1,074 & 67 \\
17 & Zamfara & 1,249 & 2,964 & 746 & 70 \\
18 & Oyo & 24,679 & 6,698 & 5,556 & 21 \\
19 & Ogun & 14,893 & 6,187 & 3,733 & 29 \\
20 & Osun & 13,634 & 2,906 & 2,929 & 18 \\
\hline
\end{tabular}

Note. Source: Extracted from Federal Ministry of Education (2010), Abuja, Nigeria Statistics Digest. 
In the 20 states under focus in the study, Bauchi State had the highest percentage (76\%) of unqualified teachers in its primary school system in 2009. This was closely followed by Jigawa (73\%), Zamfara (70\%), Katsina (68\%), and Kano and Sokoto (67\%). In the educationally advantaged states (Osun, Oyo, and Ogun) in the south-west region, Oyo State had 21\%, Ogun 29\%, and Osun 18\%. The northern part of Nigeria-Adamawa and Gombe states, had $61 \%$ and $64 \%$ of their primary school teachers unqualified respectively. This situation certainly could have become even worse with the uncontrolled increase in the birth rate, thus evoking an appointment of unqualified teachers or teachers with high qualifications but low remunerations in the guise of "state corps".

The study also focused on one of the educationally-advanced states in Nigeria—Osun State (see Table 4).

Table 4

2012/2013 Categories of Teachers in Public Secondary Schools by Type and Local Government in Osun State

\begin{tabular}{|c|c|c|c|c|c|c|c|c|c|c|}
\hline \multirow[t]{2}{*}{$\mathrm{S} / \mathrm{N}$} & \multirow[t]{2}{*}{ Local government } & \multicolumn{3}{|c|}{ Permanent teachers } & \multicolumn{3}{|c|}{$\begin{array}{c}\text { Parent-Teacher Association (PTA), } \\
\text { Osun Youth Empowerment } \\
\text { Programme (OYES), and NYSC } \\
\end{array}$} & \multicolumn{3}{|c|}{ Total number of teachers } \\
\hline & & $\mathrm{M}$ & $\mathrm{F}$ & $\mathrm{T}$ & $\mathrm{M}$ & $\mathrm{F}$ & $\mathrm{T}$ & $\mathrm{M}$ & $\mathrm{F}$ & $\mathrm{T}$ \\
\hline 1 & Atakumosa East & 49 & 7 & 56 & 53 & 45 & 98 & 102 & 52 & 154 \\
\hline 2 & Atakumosa West & 80 & 34 & 114 & 8 & 3 & 11 & 88 & 37 & 125 \\
\hline 3 & Ayedaade & 162 & 67 & 229 & 72 & 71 & 143 & 234 & 138 & 372 \\
\hline 4 & Ayedire & 53 & 29 & 82 & 51 & 27 & 78 & 104 & 56 & 160 \\
\hline 5 & Boluwaduro & 47 & 15 & 62 & 77 & 52 & 129 & 124 & 67 & 191 \\
\hline 6 & Boripe & 63 & 35 & 98 & 92 & 62 & 154 & 155 & 97 & 252 \\
\hline 7 & Ede North & 61 & 51 & 112 & 82 & 57 & 139 & 143 & 108 & 251 \\
\hline 8 & Ede South & 113 & 21 & 134 & 48 & 25 & 73 & 161 & 46 & 207 \\
\hline 9 & Egbedore & 53 & 59 & 112 & 44 & 49 & 93 & 97 & 108 & 205 \\
\hline 10 & Ejigbo & 136 & 50 & 186 & 132 & 78 & 210 & 268 & 128 & 396 \\
\hline 11 & Ife Central & 35 & 105 & 140 & 44 & 81 & 125 & 79 & 186 & 265 \\
\hline 12 & Ife East & 97 & 78 & 175 & 71 & 61 & 132 & 168 & 139 & 307 \\
\hline 13 & Ifedayo & 22 & 4 & 26 & 25 & 17 & 42 & 47 & 21 & 68 \\
\hline 14 & Ifelodun & 34 & 45 & 79 & 24 & 45 & 69 & 58 & 90 & 148 \\
\hline 15 & Ife North & 91 & 35 & 126 & 73 & 71 & 144 & 164 & 106 & 270 \\
\hline 16 & Ife South & 113 & 21 & 134 & 48 & 25 & 73 & 161 & 46 & 207 \\
\hline 17 & Ila & 52 & 39 & 91 & 48 & 38 & 86 & 100 & 77 & 177 \\
\hline 18 & Ilesa East & 90 & 200 & 290 & 144 & 201 & 345 & 234 & 401 & 635 \\
\hline 19 & Ilesa West & 65 & 149 & 214 & 95 & 86 & 181 & 160 & 235 & 395 \\
\hline 20 & Irepodun & 16 & 10 & 26 & 99 & 93 & 192 & 115 & 103 & 218 \\
\hline 21 & Irewole & 131 & 65 & 196 & 96 & 63 & 159 & 227 & 128 & 355 \\
\hline 22 & Isokan & 74 & 50 & 124 & 167 & 70 & 237 & 241 & 120 & 361 \\
\hline 23 & Iwo & 71 & 101 & 172 & 26 & 41 & 67 & 97 & 142 & 239 \\
\hline 24 & Obokun & 78 & 27 & 105 & 47 & 41 & 88 & 125 & 68 & 193 \\
\hline 25 & Odo Otin & 127 & 56 & 183 & 96 & 63 & 159 & 223 & 119 & 342 \\
\hline 26 & Ola Oluwa & 52 & 20 & 72 & 30 & 14 & 44 & 82 & 34 & 116 \\
\hline 27 & Olorunda & 139 & 199 & 338 & 104 & 230 & 334 & 243 & 429 & 672 \\
\hline 28 & Oriade & 86 & 54 & 140 & 75 & 57 & 132 & 161 & 111 & 272 \\
\hline 29 & Orolu & 34 & 32 & 66 & 70 & 55 & 125 & $104^{\circ}$ & 87 & 191 \\
\hline 30 & Osogbo & 97 & 336 & 433 & 278 & 389 & 667 & 375 & 725 & 1,100 \\
\hline \multirow[t]{2}{*}{31} & Ife East Area Office & 50 & 39 & 89 & 25 & 21 & 46 & 75 & 60 & 135 \\
\hline & Overall total & 1,366 & 1,433 & 2,799 & 1,521 & 1,558 & 3,079 & 2,887 & 2,991 & 5,878 \\
\hline
\end{tabular}

Note. Source: Osun State Ministry of Education (2013). 
The data reflect four categories of teachers in Osun State. Ifedayo local government area (LGA) had as few as 26 permanent teachers and 42 other teachers; Ifelodun LGA had 79 permanent teachers representing $53.3 \%$ of the total number of teachers. Osogbo, the state capital, had 433 permanent teachers $(39.4 \%$ of the total number of teachers). In all the LGAs, Ife East Area Office recorded $65.9 \%$ as permanent teachers. This made the Area Office to fare best in terms of the existence of permanent teachers. Atakunmosa LGA was the worst in this regard: Only $0.9 \%$ of the teaching staff in secondary schools were permanent while Odo Otin, Oriade, Ejigbo, Ede South, and Ede North had 53.5\%, 51.5\%,47\%, 64.7\%, and 46.75\% respectively in the state.

\section{Discussion}

The LEI is a variable which measures at birth the expected life span of a citizen. It is much affected by level of health care and the political terrain of a country (absence of internal dispute or external aggression resulting in loss of lives). There is no doubting the fact that the LEI, the EI, and the II have been relatively low in Nigeria. These culminated in the assessment of Nigeria by UNDP (2014) as one of the six with the lowest HDI among the petroleum exporting countries. The indicators highlighted above deserve some attention.

There is no doubt that the health care status of most countries has improved but epidemics, such as HIV/AIDS and recently the "Ebola" epidemic, have decimated the population in some African countries. Access to health facilities, number of patients per bed-space, and number of patients per doctor are indicators which have been staggering in African countries. Regarding teacher quality in the selected states, the implications of the dichotomy cannot be overemphasized. The "permanent teachers" are majorly qualified teachers with B.Ed., B.Sc.Ed., B.A.Ed., B.A./BSc. plus Post Graduate Diploma in Education (PGDE), HND plus PGDE, or awaiting PGDE results. The second category in columns 6, 7, and 8 is relatively "non-permanent teachers". Some of these non-permanent teachers are NCE holders, B.Ed, B.Sc.Ed., B.A.Ed., and HND holders who are remunerated from the PTA coffers, the OYES are paid NGN10,000 per month by the state government while the NYSC cadre are remunerated NGN19,500 by the Federal Government of Nigeria. These variations in remunerations have implications on productivity and invariably the national income since the consumption patterns of individuals are dependent on the disposable incomes. This is represented in the equations below:

$$
\begin{aligned}
& Y=C+I+G+X-M \\
& Y d=Y-\mathrm{T} \\
& Y d=f(Y)
\end{aligned}
$$

where, $Y=$ National/personal income; $C=$ Consumption; $I=$ Investment; $G=$ Government expenditure; $T$ $=$ Tax; and $Y d=$ Disposable income.

Not only that, the use of a large number of temporary teachers in the secondary schools may appear cost-effective in the market run, but resource-wasting in the short and long run. This is because declining productivity as a result of short-changing of employees by their employers may lead to students' failure (a form of wastage), which eventually affects the disposable income ( $Y d)$ at both the micro and macro levels.

Akin to this is the effect of the use of unqualified and "discomfited" teachers on students' higher repeater rate which increases both the private and social costs of education. These increases have a multiplier effect on the rate of returns $(R o R)$ to their investment in education.

This is measured by: 


$$
\mathrm{ROR}=\frac{B-C}{C}
$$

where, $B=$ Benefits; and $C=$ Costs.

Though Cameroun recorded zero rate of return to primary education (Jacques, 2006), positive RoR was computed for secondary education. Aromolaran (2002), however, computed positive RoR for both levels of education in Nigeria. This can be if repeater rates are reduced to the barest minimum.

The export $(X)$ status at the macro level is also indirectly grossly affected with the use of unqualified teachers. This has reference in the low productivity levels presumed to come from their products. Necessary skills capable of engineering higher productivity are possessed by teachers who are trained and satisfied on the job.

\section{Recommendations and Conclusion}

This article examined some key issues bothering on the connection(s) between human development and education. Human development was discussed under its indicators of LEI, EI, and II. It was observed that most states in northern Nigeria had many unqualified teachers in their primary schools. It was equally noted that the existence of unqualified teachers in $80 \%$ of the states in Nigeria would not help to improve life expectancy of the citizenry; the incomes of the citizens would be low if low productivity caused by near absence of essential skills in unqualified teachers is not checked; the use of "private corps" as practised in three states of the south-western Nigeria would discount productivity and reduce disposable incomes.

In trying to examine the coordinates of human development and quality teachers, this paper has provided insights into the need for quality and permanent teachers in both primary and secondary levels of education in Nigeria. It has also called the attention of policy makers to see beyond state education but reason along education and its role in the macro-economy. States therefore should comply with minimum standards in the employment of teachers. Only a virile teacher quality can assist in developing human capital with relevant skills, as well as guarantee human development. Though the practices of teachers would go a long way to support that quality teachers are better and necessary indicators of anticipated quality outcomes in secondary school products, the qualifications of teachers acquired through an efficient teacher education system in colleges of education (which are empowered to prepare teachers for the junior secondary schools) and universities (which train teachers for senior secondary schools in Nigeria), can be taken as a necessary condition for such quality outcomes.

\section{References}

Adamu, P. A. (2003, May). The impact of human capital on economic growth in Nigeria: An error correction approach. Paper presented at The Annual Conference of the Nigerian Economic Society, Nigeria.

Adelokun, A., Ajayi, Y., \& Oni, D. (2010). Economics of education (in a nutshell). Ibadan: Sceptre Prints Limited.

Aromolaran, A. B. (2002). Private wage returns to schooling in Nigeria: 1996-1999 (Canter Discussion Paper to 849). Retrieved July 20, 2012, from http://ssrn.com/abstract_id=345981

Babatunde, M. A., \& Adefabi, R. A. (2005, November). Long run relationship between education and economic growth in Nigeria: Evidence from the Johansan's co-integration approach. Paper presented at The Regional Conference on Education in West Africa: Constraints and Opportunities, Cornel University/CREA/Ministeratde/Education du Senegal, Dakar, Senegal.

Barouni, M., \& Broecke, S. (2012). Graduate employment and the returns to higher education in Africa. Retrieved from http://cemapre.iseg.ulisboa.pt/educonf/2e3/files/submissions_to_web/Barounia\%20Mahdi_Broeckeb\%20\%20Stijn.docx 
Bowman, M. J., \& Anderson, A. (1963). Concerning the role of education in development. In C. Geertz (Ed.), Old societies and new states. New York, N.Y.: The Free Press of Glence.

Colclough, C., Kingdon, G., \& Patrinos, H. A. (2009). The pattern of returns to education and its implications. Policy Brief, 4.

Denison, E. E. (1963). Some of the contribution of education to economic growth. Paper presented at The Economics of Education-Conference on the Residual Factor and Economic Growth, OECD.

Eicher, J. C. ( 1960). The profitability of human investment. Paris. Juillet.

Griffin, K., \& Knight, J. (1990). Human capital and economic development. Retrieved from http://www.afdb.org/fileadmin/uploads/afdb/Documents/Publications/00157612-FR-ERP-39

Hector, C. E. (2006). US economic growth-based on education. Retrieved January 20, 2015, from http://www.aiu.edu/publications/student/english

Jacques, M. (2006). An empirical analysis of the rate of returns to education in Cameroon. Retrieved from http://www.csae.ox.ac.uk/conferences/2006-eoi-rpi/papers/csae/vencatachellum

Lewis, A. W. (1961). Education and economic development. Revised version of Social and Economic Slides (10).

Patrinos, H. A. (2014). Why engage the private education sector? Washington, D.C.: World Bank-IBRD-IDA.

Perresnoud, P. (1999). Teacher competencies. Retrieved from http://ssenglishteacher.com/competenciasdocences.htm

Sackey, H. A. (2008). Private returns to education in Ghana: Implications for investments on schooling and migration (African Economic Research Consortium Research Paper).

Saharawati, B. S. (2008). The rate of returns to investment in education: A case study of polytechnic diploma graduates (Unpublished M.A. thesis, Universiti Sains Malaysia).

Schultz, T. W. (1961). Investment in human capital. American Economic Review, 51, 116-124.

Schultz, T. W. (2001). Returns to agriculture education in vocational schools. Education Economics, 12(2), 111-124.

United Nations Development Programme (UNDP). (1990). Report title. Retrieved from which webisite?

UNDP. (2012). Annual report. Retrieved December 16, 2014, from http://www.undp.org/content/undp/en/home

UNDP. (2014). Human development report. Retrieved from http://www.undp.org/content/undp/en/home/library page/hdr/2014-human-development-report

United Nations Education Scientific and Cultural Organization (UNESCO). (1962). The relations between literacy and economic development. Paris: UNESCO-World Campaign for Universal Literacy.

UNESCO. (2014). Education for all global monitoring report. Retrieved December 20, 2014, from http://www.cecomm.org.uk/publications/17/-education-for-all-global-monitoring-report-2014

United Nations International Children's Emergency Fund. (UNICEF). (2012). UNICEF annual report. Retrieved December 15, 2014, from http://www.unicef.org/publications/index

World Bank. (2013). World development reports. Retrieved from http://econ.worldbank.org/external/default/main 